Jurnal Ekonomi Pembangunan, 18 (2), 2017, 256-264

\title{
Bank Efficiency Analysis and Stock Return in Indonesia Stock Exchange (IDX)
}

\author{
Riwi Sumantyo*, Wayan Nur Aziz Tanca Tresna \\ Department of Economics, Faculty of Economics and Business, Sebelas Maret University, Indonesia \\ *Corresponding Author: riwi.solo@gmail.com
}

Received: April 2017 | Revised: October 2017 | Accepted: November 2017

\begin{abstract}
This study aimed to analyze the efficiency of the banks which are listed in Indonesia Stock Exchange (IDX) and empirically tests the bank effects on the stock returns of each bank. The sample of this study is all banks which are listed in the IDX during the period of 2009 to 2016. Data Envelopment Analysis (DEA) used to measure the bank efficiency in each Decision making units (DMUs), which are obtained as the maximum ratio to know the efficiency level of stock performance by using DEA methods. From the total of 25 banks analyzed, acquired six banks which were always efficient in the period of 2009 to 2016. Moreover, to know the relation between the bank efficiency and the stock return, the regression testing is done by using fixed effect models. The result shows that the bank efficiency of Indonesian banks does not affect their stock return.
\end{abstract}

Keywords: Bank Eefficiency; Data Envelopment Analysis (DEA); stock return; fixed effect models JEL Classification: D51, E43, G21

How to cite: Sumantyo, r., \& Tresna, W. (2017). Bank Efficiency Analysis and Stock Return in Indonesia Stock Exchange (IDX). Jurnal Ekonomi Pembangunan: Kajian Masalah Ekonomi dan Pembangunan, 18(2), 115-124. doi:https://doi.org/10.23917/jep.v18i2.3960

DOI: https://doi.org/10.23917/jep.v18i2.3960

\section{Introduction}

Bank is the most important financial establishment and it has big impact in economy, both in macro and micro. In Indonesia, bank has $80 \%$ market share of all financial system available. Considering the concern of the bank role in Indonesia, it should evaluate the performance adequately before deciding a decision (Abidin, 2007). There are at least 4 kind of performance evaluations which can be measured, such as performance relating regulatory compliance like the value of adequacy ratio, statutory reserve. The second is performance related to finance, as Return On Equity (ROE), Return On Asset (ROA), Management (M), Earning (E), Liability (L), Sensitivity market to risk (S), which is commonly abbreviated to CAMELS. The third is performance related to the function of intermediary institution as Loan to Deposit Ratio (LDR), and the last one is performance related to work efficiency.

Besides being a very important financial establishment, bank in Indonesia also has something good to attract the investors. Now days, many investors begin to look bank as an investment place where they can invest stock in bank. Stock or bank stock becomes one of favored investment because it has some excellences; the first, stock has high return. By selecting the right stock, the investment will give huge long-term profit instead of another kind of investment.

However, before determining to invest in bank stock, surely the investor has to be an expert observant on selecting which stock is efficient. So that, they can get huge stock returns. As stated 


\section{Jurnal Ekonomi Pembangunan, 18 (2), 2017, 256-264}

by Hadad, et al (2003), efficiency is a kind of performance parameters which is theoretically being a basic performance of an organization. The competence to produce the maximum output by using the available input is the performance parameters desired. When measuring the efficiency, an organization is faced to condition how to get optimum output by using the available input, or get minimum input with certain level of output.

Measuring performance of a stock is the main thing should do before investing in that asset. The measurement of stock performance efficiency can be analyzed by Data Envelopment Analysis (DEA). DEA is developed to measure the level of performance or productivity of an organizational unit group. DEA is non-parametric methodology based on linear programming which counts on weight ratio of output towards input in each production unit (decision making units). This measurement is examined to find out possibility utilization resource used to get optimum output. The evaluated productivity in DEA is minimizing resources (input) without decreasing the amount of output has been produced, or maximization output which may be produced without raising the resources.

Based on the data above, in this study the writer used Data Envelopment Analysis (DEA) approach. DEA approach does not involve specification and econometric estimation from statistical facts or parametric function. DEA also provides pricewise linear frontier by forming envelop from observed data. DEA assumes there is no random error, unlike SFA. The advantage of DEA approach is using simple structure on efficient frontier and it doesn't need assuming custody that all organizations use the same production technology (Dranke and Hall, 2003).

Basically, this research is a continuous study of previous research. The focus of this research is selecting stock and verification- does efficient bank stock always have return stock using object of bank research listed in Indonesia stock exchange (BEI) on 2009-2016. The higher volume of offering demanding of stock, the bigger impact to the stock price fluctuation and the decreasing number of stock trading volume proves the interest of the society to that stock. Stock trading volume is also indicator used in technical analysis on stock price assessment and an instrument which can be used to analyze capital market reaction toward information through parameter of activity movement in stock trading volume in market.

Many studies examines this research. Vardar (2013) investigates the link between the cost and profit efficiency scores of the banks in the Central and Eastern European Countries as well as Turkey along with their stock price performance to determine whether the efficiency scores are priced accordingly in bank stocks. The results indicate that changes in profit efficiency estimates have a positive and significant impact on stock returns; however, a significant but negative relationship is found between changes in cost efficiency and stock returns.

Abuzayed, Molyneux and Al-Fayoumi (2009) examines arket value, book value and earnings . Their result are First, it is found that earnings (and its components) are value relevant and explain the gap between market and book values. Secondly, cost efficiency, as an economic performance measure, provides incremental information, not contained directly in banks financial statements, to the market. Overall it is found that the components of net income are more important than aggregate net income in explaining bank value. Furthermore, bank operational efficiency adds incremental information in explaining the gap between market and book value. These results support the view that stock prices aggregate signals received by the market as well as from firm's accounting systems.

Altunbas, et al (2000) examines efficiency and risk in Japanese banking. The result are optimal bank size is considerably smaller when risk and quality factors are taken into account when modelling the cost characteristics of 


\section{Jurnal Ekonomi Pembangunan, 18 (2), 2017, 256-264}

Japanese banks, the level of financial capital has the biggest influence on the scale efficiency estimates. X-inefficiency estimates, in contrast, appear less sensitive to risk and quality factors. They suggests that scale inefficiencies dominate $\mathrm{X}$-inefficiencies. These are important findings because they contrast with the results of previous studies on Japanese banking. In particular, the results indicate an alternative policy prescription, namely, that the largest banks should shrink to benefit from scale advantages. It also seems that financial capital has the largest influence on optimal bank size.

Chen and Zhang (2007) in "How do accounting variables explain stock price movements? Theory and evidence" concluded that the predicted roles of all identified factors. The model explains about $20 \%$ of the cross-sectional return variation, with cash-flow-related factors (as opposed to changes in discount rates) accounting for most of the explanatory power. The properties of the model are robust across various subsamples and periods.

Erdem and Erdem (2008) examines turkish banking efficiency and its relation to stock performance. Their result are economi efficiency scores of banks obtained from DEA model was related to their stock prices to determine whether there is an explanatory power of efficiency scores on stock price returns. The average banks' efficiency decreased from 0.781 in 1999 to 0.504 in 2001 and started to increase after this year except the year of 2003 indicating that financial crises affected the efficiency scores of the banks. During the time period 1998 to 2004, six banks appeared to be technically efficient at least once.

Fries and Taci (2005) examines Cost efficiency of banks in transition: Evidence from 289 banks in 15 post-communist countries. They concluded that banking systems in which foreignowned banks have a larger share of total assets have lower costs and that the association between a country's progress in banking reform and cost efficiency is non-linear. Early stages of reform are associated with cost reductions, while costs tend to rise at more advanced stages. Private banks are more efficient than state-owned banks, but there are differences among private banks. Privatized banks with majority foreign ownership are the most efficient and those with domestic ownership are the least.

Girardone, Molyneux and Gardener (2004) examines Analysing the determinants of bank efficiency: The case of Italian banks. they concluded that The results show that mean $\mathrm{X}$-inefficiencies range between 13 and 15 per cent of total costs and they tend to decrease over time for all bank sizes. Economies of scale appear present and significant, being especially high for popular and credit co-operative banks. Moreover, the inclusion of risk and output quality variables in the cost function seems to reduce the significance of the scale economy estimates.

Kirkwood and Nahm (2006) examines australian banking efficiency and relation to stock returns. They concluded that the major banks have improved their efficiency in producing banking services and profit, while the regional banks have experienced little change in the efficiency of producing banking services, and a decline in the efficiency of producing profit. An attempt is made to relate the changes in efficiency to stock returns. Results indicate that for our sample, changes in firm efficiency are reflected in stock returns.

Liadaki and Gaganis (2010) in their study "Efficiency and stock performance of EU banks: Is there a relationship?" concluded that the change in profit efficiency has a positive and significant impact on stocks prices; however, there is no relationship between changes in cost efficiency and stock returns.

Mamatzakis, Staikouras, and KoutsomanoliFilippaki (2008) in their study "Bank efficiency in the new European Union member states: Is there convergence?" concluded that a generally low level of cost and an even lower level of profit efficiency, whilst we do not observe marked differences of inefficiency scores across countries. Foreign banks outperform both state-owned and domestic private-owned banks in terms of 


\section{Jurnal Ekonomi Pembangunan, 18 (2), 2017, 256-264}

profit efficiency, though results are less clear in the case of cost efficiency. In addition, B- and $\sigma$-convergence criteria indicate some convergence in cost efficiency across the new member states, yet no convergence appears to have been achieved in terms of profit efficiency.

Pasiouras, Liadaki,, and Zopounidis (2008) examines Bank efficiency and share performance: Evidence from Greece. They Concluded that a positive and statistically significant relationship between annual changes in technical efficiency and stock returns, while changes in scale efficiency have no impact on stock returns.

Sufian and Majid (2006) examines Banks' Efficiency and Stock Prices in Emerging Markets: Evidence from Malaysia. They concluded that during the period of study, the X-efficiency of Malaysian listed banks was on average significantly higher compared to the P-efficiencies. The P-inefficiency was largely due to inefficient production of profits rather than the wrong scale of operations.

Based on that matter, the writer raise a research entitled Bank Efficiency Analysis and Return Stock in Indonesia stock exchange using DEA approach to find out which bank is efficient. And then analyzing empirically using regression models for Panel Data Analysis Fixed Effect Models (FEM) between bank efficiency and return stock in each period, does efficient bank stock definitely have high return stock or does not.

\section{Research Method}

In analyzing bank efficiency in Indonesia, this research use Data Enveelopment Analysis (DEA) technique. DEA principles itself was introduced by Farrel (1957) which is developed extensively by Charnes, Cooper and Rhodes (1978), commonly called as CCR. DEA is used to measure efficiency in each Decision making units (DMUs), gotten as maximum weight output ratio in input weight. Efficient production happens when the revealed output is higher than input has been decided. The weight of a ratio is declared by same ratio limit for a DMU, it has to be lower or same with group. Definition of efficiency measurement permits various output and input without weighting at first. The various input and output can be reduced to single 'virtual' input and single 'virtual' output by optimal weight. Then, the measurement of efficiency is a multiple function from 'virtual input-output' combination.

DEA is a relative measurement of efficiency, it measures unit inefficiency existed rather than another unit considering DEA which has 100\% efficiency level. It means that this unit is the most efficient set data in certain time. Another advantage is DEA can find out the source of inefficiency with potential measurement improvement from each input. DEA also cannot do statistic test like econometric. Therefore, this two approaches will afford similar measurement in efficiency when the data complete and accurate. If the econometric needs so many data, the DEA which is highly vulnerable with zero, negative and lower number close to zero, it can cause highest weight fluctuation until unlimited.

In DEA approach, we don't put random error. As the consequence, DEA approach can not consider macro variable factors such as the size differences of a bank assets or regulation, considering the bank efficiency level.

DEA method was made as the auxiliary tools to evaluate activity performance in entity unit (organization). DEA can combine different input and output into an efficiency measurement.

\section{Result and Discusions}

Population used in this research is banks listed in Indonesia Stock Exchange in period 20092016. Sample of this data use purposive sampling which means putting data by selecting sample participant based on certain criteria (Cooper and Emory, 1995). These criteria are:

a. Banks listed in Indonesia Stock Exchange which have released complete report on 2009 - 2016

b. Banks having complete data research including total deposits, interest expense, total loans, interest income, and non-interest income. 
Jurnal Ekonomi Pembangunan, 18 (2), 2017, 256-264

Table 1. The List Of 25 Bank Samples

\begin{tabular}{clc}
\hline No & \multicolumn{1}{c}{ Emiten } & Bank Code \\
\hline 1 & BANK ARTHA GRAHA & INPC \\
2 & BANK BUKOPIN & BBKP \\
3 & BANK BUMI ARTA & BNBA \\
4 & BANK CAPITAL INDONESIA & BACA \\
5 & BANK CENTRAL ASIA & BBCA \\
6 & BANK CIMB NIAGA & BNGA \\
7 & BANK DANAMON & BDMN \\
8 & BANK EKONOMI RAHARJA & BAEK \\
9 & BANK MANDIRI & BMRI \\
10 & BANK MAYAPADA INTERNASIONAL & MAYA \\
11 & BANK MEGA & MEGA \\
12 & BANK NEGARA INDONESIA & BBNI \\
13 & BANK NUSANTARA PARAHYANGAN & BBNP \\
14 & BANK OCBC NISP & NISP \\
15 & BANK OF INDIA INDONESIA/SWADESI & BSWD \\
16 & BANK PAN INDONESIA & PNBN \\
17 & BANK PERMATA & BNLI \\
18 & BANK PUNDI INDONESIA & BEKS \\
19 & BANK QNB KESAWAN & BKSW \\
20 & BANK RAKYAT INDONESIA & BBRI \\
21 & BANK RAKYAT INDONESIA AGRONIAGA & AGRO \\
22 & BANK TABUNGAN NEGARA & BBTN \\
23 & BANK TABUNGAN PENSIUNAN NASIONAL & BTPN \\
24 & BANK VICTORIA INTERNASIONAL & BVIC \\
25 & BANK WINDU KENTJANA INTERNASIONAL & MCOR \\
\hline & &
\end{tabular}

Source: Fact Book IDX, Processed data

c. Banks being active member in trading stock and its stock price is listed in Indonesia Stock Exchange.

Data used in this research is total deposits, interest expense, total loans, interest income, non-interest income and stock return. These data gained from financial report and annually bank stock return from Indonesia Stock Exchange or commonly called as Bursa Efek Indonesia (BEI). The variables like Abuzayed, Molyneux and Al-Fayoumi (2009), Vardar (2013), Pasiouras, Liadaki,, and Zopounidis (2008) Kirkwood and Nahm (2006)'s studies. There are 25 banks can be categorized in that categorization.
From 25 bank sample used in this research, they would be analyzed to find out which bank is categorized as efficient banks. To measure the value of bank efficiency, the researcher use Data Envelopment Analysis (DEA). The following steps below are taken to determine efficiency stock using Data Envelopment Analysis:

a. Determine the input and output variables to be taken into account in the analysis process.

b. Processing the data with Data Envelopment Analysis using software

Max DEA. there are two processing stages. Step1: Prepare Data At this stage, all data (DMU, input, and output) are specified and packaged into a shape of the table which will then be processed at a later stage. Step2: 


\section{Jurnal Ekonomi Pembangunan, 18 (2), 2017, 256-264}

Run The Model, The first stage of step2, the data has been prepared at the previous stage are processed in accordance with the methods and approaches that are pre-set (model Variable Returns to Scale or known by the BCC and approachoutput-oriented). Then, the last stage of step2, the results will be processing displayed in the form of the result table.

c. Interpret the resulting data processed DEA. At this stage will describe the result of the processing of data by using the data envelopment analysis. This stage will elaborate DMU which is efficient and inefficiencies as well as. How to repair efficiency by viewing the multiplier and the target value that is generated by the DMU made reference.

The hypothesis in this study was done based on the results (score) data processing using the Max DEA Software. This analysis will test levels efficiency based on input and output that has been previously determined, in this case efisisensi banking is based on the DEA method. Formulation of mathematically the hypothesis in this study are as follows:

Ho: $\mu=1.00$

$\mathrm{H} 1: \mu \neq 1.00$

Description:

$\mu=$ DEA efficiency Score for each sample (25 Banks)

Table 2 Calculation Result of DEA BCC Efficiency

\begin{tabular}{|c|c|c|c|c|c|c|c|c|c|}
\hline DMU & 2009 & 2010 & 2011 & 2012 & 2013 & 2014 & 2015 & 2016 & Note \\
\hline INPC & 0.85 & 0.74 & 0.82 & 0.88 & 0.86 & 0.87 & 0.87 & 0.87 & inefficient \\
\hline BBKP & 0.82 & 0.83 & 0.87 & 0.88 & 0.84 & 0.76 & 0.76 & 0.76 & inefficient \\
\hline BNBA & 1.00 & 0.87 & 0.91 & 1.00 & 0.98 & 0.95 & 0.95 & 0.95 & inefficient \\
\hline BACA & 0.68 & 0.55 & 0.58 & 0.61 & 0.66 & 0.64 & 0.64 & 0.64 & inefficient \\
\hline BBCA & 1.00 & 1.00 & 1.00 & 1.00 & 1.00 & 1.00 & 1.00 & 1.00 & efficient \\
\hline BMGA & 1.00 & 0.99 & 1.00 & 1.00 & 0.94 & 0.98 & 0.98 & 0.98 & inefficient \\
\hline BDMN & 1.00 & 1.00 & 1.00 & 1.00 & 1.00 & 1.00 & 1.00 & 1.00 & efficient \\
\hline BAEK & 0.73 & 1.00 & 0.99 & 1.00 & 0.99 & 0.87 & 0.87 & 0.87 & inefficient \\
\hline BMRI & 1.00 & 1.00 & 1.00 & 1.00 & 1.00 & 1.00 & 1.00 & 1.00 & efficient \\
\hline MAYA & 0.73 & 0.79 & 0.82 & 0.80 & 0.83 & 0.78 & 0.78 & 0.78 & inefficient \\
\hline MEGA & 0.70 & 0.69 & 0.74 & 0.74 & 0.67 & 0.72 & 0.72 & 0.72 & inefficient \\
\hline BBNI & 1.00 & 1.00 & 0.92 & 1.00 & 1.00 & 1.00 & 1.00 & 1.00 & inefficient \\
\hline BBNP & 0.81 & 1.00 & 0.89 & 0.88 & 0.82 & 0.87 & 0.87 & 0.87 & inefficient \\
\hline NISP & 0.86 & 1.00 & 1.00 & 0.95 & 0.92 & 0.92 & 0.92 & 0.92 & inefficient \\
\hline BSDW & 1.00 & 1.00 & 1.00 & 1.00 & 1.00 & 1.00 & 1.00 & 1.00 & efficient \\
\hline PNBN & 0.82 & 0.88 & 0.93 & 0.97 & 0.87 & 0.86 & 0.86 & 0.86 & inefficient \\
\hline BNLI & 0.92 & 1.00 & 0.94 & 0.98 & 0.91 & 0.90 & 0.90 & 0.90 & inefficient \\
\hline BEKS & 1.00 & 1.00 & 0.72 & 1.00 & 1.00 & 1.00 & 1.00 & 1.00 & inefficient \\
\hline BKSW & 0.81 & 0.89 & 0.88 & 0.96 & 1.00 & 1.00 & 1.00 & 1.00 & inefficient \\
\hline BBRI & 1.00 & 1.00 & 1.00 & 1.00 & 1.00 & 1.00 & 1.00 & 1.00 & efficient \\
\hline AGRO & 0.96 & 1.00 & 1.00 & 0.95 & 0.92 & 0.98 & 0.98 & 0.98 & inefficient \\
\hline BBTN & 1.00 & 1.00 & 1.00 & 1.00 & 1.00 & 1.00 & 1.00 & 1.00 & efficient \\
\hline BTPN & 0.94 & 1.00 & 1.00 & 0.99 & 1.00 & 1.00 & 1.00 & 1.00 & inefficient \\
\hline BVIC & 0.75 & 0.76 & 0.62 & 0.62 & 0.66 & 0.65 & 0.65 & 0.65 & inefficient \\
\hline MCOR & 0.74 & 0.92 & 0.86 & 0.82 & 0.81 & 0.85 & 0.85 & 0.85 & inefficient \\
\hline
\end{tabular}

Sumber: Processed by OSDEA

$\mathrm{H} 1$ rejected and Ho is accepted if all of the samples have a value (score) the efficiency of 1.00, so too 
otherwise the $\mathrm{H} 1$ is accepted and $\mathrm{H} 0$ is rejected if there is a difference in value on each samples, or in other words there are one or more samples have values efficiency $<1.00$ or inefficient.

Table 2 indicates the result of processing with DEA BCC model using OSDEA software. Seen from the table above, we can find out that on first year of research 2009 there are 10 banks having efficient value. Efficient banks are banks having scale of efficiency amount 1. On 2010 many banks have efficient value, 14 banks. Therefore just 6 banks of them have consistent efficiency every year. They are BBCA (Bank Central Asia), BDMN
(Bank Danamon), BMRI (Bank Mandiri), BSWD (Bank of India Indonesia Swadesi), BBRI (Bank Rakyat Indonesia) and BBTN (Bank Tabungan Negara).

After getting the result of efficiency and stock return for each bank in each year, then it will be examined by Fixed effect models regression to find out the effect of efficient bank towards the stock performance, seen from stock return in each period. Then, analyzing using Fixed effect models method by importing these table to Eviews analysis tool. After being analyzed, there will be a result as in Table 3.

Table 3. Panel Model

\begin{tabular}{cc}
\hline Panel Model & BANK \\
\hline & EGLS \\
Intercept & 0.90537 \\
& 0 \\
RS & -0.0002 \\
& 0.4944 \\
R2 & 0.8391 \\
F-Statistic & 29.8665 \\
\hline
\end{tabular}

In the table 3 , return is defined as dependent variable reflecting stock return, while efficiency is defined as variable reflecting the value of bank efficiency. Interpretation gotten on table 6 is a coefficient to efficiency variable is -0.000207 with probability amount 0.4994 , by using $5 \%$ significant (moderate test), thus the efficiency variable is not significant because the level of efficiency variable is higher than $5 \%$, which is $0.4994(49 \%)$.

Seen by the calculation result above, it can be concluded that there is no effect between bank efficiency in Indonesia and its stock return (HI was rejected). Efficiency should be a factor in deciding; foes the bank use input to produce maximum output. One of the bank efficient value calculation in Indonesia use Operating Expenses and Operating Income ratio. Calculation result using OEOI is different with the researcher's calculation. The difference is on different variable applied while calculation process, so that the result is different though. Based on completed calculation, bank which has similar amount of input and output has 100\% efficiency level than the bank which has higher input rather than its output.

Many factors can be the reason of no effect between efficiency values towards stock return. Investor can buy or sell the stock which still follows applicable regulation such as using CAMEL method (Capital, Asset, Management, Earning and liquidity). In CAMEL method, calculating efficiency using OEOI method where the investor decision is more depend on earning factor income. Even though there is another kind of factor influencing the investment decision in stock which has to be considered. In various discourse, the weight efficiency used to take decision to invest in stock market is just $5 \%-10 \%$. That matter can influence investor decision on investing in bank stock.

By weighting like that, it would be proper if bank with $100 \%$ efficiency uncertainly has high 


\section{Jurnal Ekonomi Pembangunan, 18 (2), 2017, 256-264}

stock return. Based on DEA calculation, it has not reflected the real condition of the bank. It is influenced by several factors, they are:

a. Problematic credit cannot be put to the efficiency calculation

b. The investor character in Indonesia has not oriented on investment, but still oriented on capital gain

\section{Conclusion}

This research aims to find out and analyze the relation between the effects of bank efficiency towards its stock return, concerning the case study on banks listed in IDX on 2009-2016. This research use Data Envelopment Analysis and Fixed effect models it can be concluded that Based on Data Envelopment Analysis processing, it includes input variables such as total deposits, interest expense, and output variable such as total loans, interest income and non-interest income. From DEA BCC calculation result, there are 6 banks which always determine efficiency value every year. They are BBCA (Bank Central Asia), BDMN (Bank Danamon), BMRI (Bank Mandiri), BSWD (Bank of India Indonesia Swadesi), BBRI (Bank Rakyat Indonesia) and BBTN (Bank Tabungan Negara). After holding test between bank efficiency each year towards stock return in each bank using Fixed effect models (FEM) regression, it can be concluded that bank efficiency has mo effect toward the stock performance in that bank, which is measured by its stock return.

For the next scholar and researcher, they can use DEA model to look for stock efficiency, but they should try to add suitable variable to make more accurate research. The factor that may be added is like NPL (Non-Performing Loan) or problematic credit. Thus, since there is data from bank problematic, it should be managed better. Then, researcher can use another company's sample by considering more on fundamental value of the company, so it can determines the effect of company efficiency toward its stock return from company's closing year stock price.

\section{Reference}

Abidin, Z. (2007), Kinerja Efisiensi Pada Bank Umum Proceeding PESAT (Psikologi, Ekonomi, Sastra, Arsitek, \& Sipil), 2 (8): 113-119

Abuzayed, B., Molyneux, P., Al-Fayoumi, N. (2009), Market Value, Book Value and Earnings: Is Bank Efficiency a Missing Link? Managerial Finance, 35(2): 156-179.

Altunbas, Y., Liu, M.H., Molyneux, P., Seth, R. (2000), Efficiency and Risk in Japanese Banking. Journal of Banking \& Finance, 24(10), 1605-1628.

Charnes, A., Cooper, W., W and Rhodes, E. (1978), Meausuring the Efficiency of Decision Making Units, European Journal of Operational Research, 2 (6), 429-444

Chen, P. \& Zhang, G. (2007), How do Accounting Variables Explain Stock Price Movements? Theory and Evidence. Journal of Accounting and Economics, 43, (2-3): 219-244.

Cooper, D. R. and Emory, C. W. (1995), Business Research Methods, $5^{\text {th }}$ edition, Richard D. Irwin Inc.

Dranke, L dan M.J.B Hall. (2003), Efficienty in Japanese Banking: an Empirical Analysis, Journal of Banking and Finance, 27 (5): 891-917.

Erdem, C. and Erdem, M.S. (2008), Turkish Banking Efficiency and its Relation to Stock Performance. Applied Economics Letters, 15(3), $207-211$.

Farrel. M. J (1957), The Measurement of Productive Efficiency, Journal of the Royal Statistical Society, 120 (3): 253-290.

Fries, S. and Taci, A. (2005), Cost Efficiency of Banks in Transition: Evidence from 289 Banks in 15 Post Communist Countries. Journal of Banking and Finance, 29 (1), $55-81$.

Girardone, C., Molyneux, P., Gardener, E.P.M. (2004), Analysing the Determinants of 
Jurnal Ekonomi Pembangunan, 18 (2), 2017, 256-264

Bank Efficiency: The Case of Italian Banks. Applied Economics, 36 (3), 215-227

Hadad, M. D, Santoso, W, Ilyas, D, Mardanugraha, E. (2003), Pendekatan Parametrik Untuk Efisiensi Perbankan Indonesia, Data Envelopment Analysis, Buletin Ekonomi Moneter dan Perbankan.

Kirkwood, J. and Nahm, D. (2006), Australian Banking Efficiency and Its Relation to Stock Returns. The Economic Record, 82 (258), 253-267

Liadaki A., and Gaganis, C. (2010), Efficiency and Stock Performance of EU banks: Is There Relationship? Omega, 38(5), 254-259.

Mamatzakis, E., Staikouras, C., and Koutsomanoli-Filippaki, A. (2008), Bank Efficiency in the New European Union Member States: Is There Convergence?
International Review of Financial Analysis, 17 (5), 1156-1172

Pasiouras, F., Liadaki, A., and Zopounidis, C. (2008), Bank Efficiency and Share Performance: Evidence from Greece. Applied Financial Economics, 18 (14), 1121-1130.

Sufian, F., and Majid, M-Z. A. (2006), Banks' Efficiency and Stock Prices in Emerging Markets: Evidence from Malaysia. Journal of Asia-Pacific Business, 7(4), 35-53.

Vardar, G (2013), Efficiency and Stock Performance of Banks in Transition Countries: Is There A Relationship? International Journal of Economics and Financial Issues, 3 (2), 355-369 